\title{
A STUDY OF THE INFLUENCE OF THE
}

INTERVAL BETWEEN MATINGS UPON THE

\section{REPRODUCTIVE PERFORMANCE}

\section{OF THE ALBINO RAT}

\author{
Arthur H. Smith, William E. Anderson \\ and Rebecca B. Hubbell
}

\section{Uimmertirut \\ Aquritultuxal Trxperiment Station \\ ANEu Thaten}





\title{
A STUDY OF THE INFLUENCE OF THE
}

\section{INTERVAL BETWEEN MATINGS UPON THE \\ REPRODUCTIVE PERFORMANCE \\ OF THE ALBINO RAT}

\author{
Arthur H. Smith, Willink E. Anderson \\ AND Rebecca B. HubBell
}

\begin{abstract}
Much of our present-day knowledge of nutrition has been derived II from experimentation with small animals such as rats and mice because suitable diets can be economically prepared in quantities sufficient for long periods. In 1911, Osborne and Mendel (26) wrote:

"Minor deficiencies may fail to become conspicuous in even comparatively long periods of time in the case of animals whose size and span of life indicate a considerable store of reserve material. ... Furthermore the various stages of growth and maturity are completed in the smaller animals within relatively short periods of time, so that the permanent effects of any dietary become apparent within a range of days or months that is not outside of ordinary experimental possibilities of observation." (See also 27).
\end{abstract}

A survey of many of the studies that have been made with the albino rat since this statement was written shows that investigators early appreciated the need for a higher degree of uniformity in the results of experiments with this species than is ordinarily obtained. The breeding and care of the rat have therefore received considerable attention. There are well-known colonies today in which the animals have been maintained on carefully planned rations for many years, and in which the general breeding procedure has been controlled. Workers in this field do not need to be reminded of the records of the colonies at the Wistar Institute, in Sherman's laboratory at Columbia University, or at the Connecticut Agricultural Experiment Station where Osborne and Mendel conducted their investigations. In the management of these, as well as of many other colonies, every effort has been made to provide the investigator with animals of uniform strain and known nutritional background.

As a result of care in breeding and in the application of more adequate knowledge of nutrition, there has been a marked change in the rate of growth of this laboratory animal during the past 30 years. The decrease in the time required for male rats to grow from $60 \mathrm{gm}$. to $200 \mathrm{gm}$. hody weight has been discussed in earlier papers from this laboratory $(28,22,24)$ and from the Laboratory of Physiological Chemistry at Yale $(1,37)$.

Note: This investigation, conducted in the Biochemical Laboratory of this Station, was started in 1930 by Professors Arthur H. Smith and Wm. E. Anderson of Yale University at the invitation of Professor Lafayette B. Mendel. The expenses were shared by the Connecticut Agricultural Experiment Station and the Carnegie Institution of Washington. 
In striking contrast to a daily gain of approximately $2 \mathrm{gm}$. recorded by various workers in the period from 1906 to $1915(4,5,26)$ are the figures of 4,5 , or even $6 \mathrm{gm}$. daily gain characteristic of the animals in some of these colonies today. Expressed in a different way, Donaldson and his collaborators reported in 1906 a weight of $165 \mathrm{gm}$. for rats 100 days of age; whereas in 1915 (10) animals of the same colony reached a weight of 200 gm. at this age. Thirteen years later, Smith and Bing (37) at Yale observed in their colony a body weight of $315 \mathrm{gm}$. for rats of the same sex and age. This change represents an increase of approximately 100 percent in rate of growth.

In a recent paper, Mendel and Hubbell (23) have recorded observations concerning the relation of diet to rate of growth in the colony of rats at the Connecticut Agricultural Experiment Station. Data collected over a period of 23 years show a marked increase in body weight for all ages. Whereas in 1912 the weight at weaning (21 days of age) of male rats in this colony was only $23 \mathrm{gm}$., and the body weight at 100 days was only $165 \mathrm{gm}$., in 1935 the corresponding figures were 48 and $364 \mathrm{gm}$. respectively. These investigators also remark that "the improved growth rate has been accompanied by superior reproductive performance."

The foregoing evidence of the enhanced rate of growth of the albino rat emphasizes the possibilities of development as the nutritional environment approaches an optimum. As indications of changes in the organism which accompany variations in rate of growth may be cited the independence of body size and proportions (29), the dependence of the mineral content of the bones (24), and the definjte alteration in the chemical composition of the increments of growth with respect to fat, protein, water, and ash (30). The possible effect of both rapid growth and favorable nutrition on reproduction is of practical as well as theoretical interest.

One of the details of the reproductive cycle which has been held to be of great significance is the interval between successive pregnancies. According to the customary breeding procedure in this laboratory, a female is mated only three times, with a period of not less than three weeks between weaning a litter and subsequent remating. In other colonies a much shorter period of rest is allowed. At times, in this as well as in other laboratories, animals have been bred only when young were needed for experimental purposes; thus the interval between matings has not always been unjform. In view of this variation in breeding procedure and of the possible influence of the mating interval upon rats in which unusually rapid somatic development is promoted by favorable nutrition, it seemed of interest to study the effect of a superior colony ration under different conditions of mating, in order to determine whether a diet that seemed adequate when the females were permitted a rest of three weeks would be satisfactory if the period of rest were reduced to two weeks, or to one week.

Accordingly, the breeding performance of rats of the Connecticut Agricultural Experiment Station strain was followed through several successive generations in order to study the relationship of the interval between pregnancies to the number and size of litters and to the weight of the young at weaning. The present report describes results obtained over a period of six years on a total of 474 breeding females and 9,261 weanling young. 
The ration used was a modification of that suggested by Maynard (20): G.L.F. calf meal, 97 percent, and cod liver oil, 3 percent.

The addition of vitamin $A$, in the form of cod liver oil, was made because of extensive experimental evidence that shows the manifold directions in which this dietary factor can affect reproduction. For example, it is known that the integrity of the vaginal epithelium, the maintenance of fetal attachments to the uterus throughout normal gestation, and the vigor of the young, are closely associated with a satisfactory level of vitamin $\mathrm{A}$ in the ration $(38,2,6,18,19,17)$.

The composition of the calf meal was as follows:

\section{Calf Meal}

$\begin{array}{lclr} & \% & & \% \\ \text { Linseed oil meal } & 15.0 & \text { Oat flour } & 15.0 \\ \text { Ground malted barley } & 10.0 & \text { Yellow corn meal } & 20.0 \\ \text { Wheat red dog flour } & 22.0 & \text { Steamed bone meal } & 1.0 \\ \text { Dried skim milk } & 15.0 & \text { Ground limestone } & 1.0 \\ & & \text { Sodium chloride } & 1.0\end{array}$

This represents the formula at the start of this experiment in May, 1930. The meal used beginning in November of that year was modified slightly by the manufacturers, 1.5 percent soluble blood meal being substituted for an equal quantity of dried skim milk. In November, 1933, the ground limestone was omitted and 1 percent yellow corn meal was added. Beginning January, 1935, the calf meal formula was further changed to include 0.25 percent cod liver oil reinforced with a vitamin concentrate that contained 3000 units (U.S.P.) of vitamin A and 400 units (U.S.P.) of vitamin D per gram of concentrate. On the basis of this final change, a mixture that contained 98 percent of calf meal and 2 percent of cod liver oil was fed for the remainder of the experiment.

It has been the practice in this laboratory since 1912 to include in the dietary of the nursing mothers some readily available concentrated food which not only supports more satisfactory lactation, but serves also to lessen the difficulty of transition for the young from mother's milk to an experimental ration (23). Accordingly, in this experiment, the lactating mothers were given, in addition to the calf meal food, the following "paste food": casein, 25 percent; whole milk powder, 25 percent; wheat embryo, 20 percent; and lard, 30 percent. $^{1}$ Young rats received paste food for three weeks after weaning, or until they were six weeks old. ${ }^{2}$

Until October, 1932, $10 \mathrm{gm}$. of lettuce were fed to each rat daily. After this date, for economy, the same amount of lettuce was given only once a week and, in addition, $3 \mathrm{gm}$. of wheat embryo per week were fed to the rats that did not receive "paste food". Throughout the study, all of the animals received $1 \mathrm{gm}$. of dried yeast daily.

1 That the known destructive action of lard on vitamin $\mathbf{E}(7,3,15)$ did not play a part in these experiments seems assured by the high ratio of total vitamin $E$. (wheat germ and lettuce) to lard in the dietary regimen and by the success of the routine breeding procedure on a similar dietary, but without lettuce.

${ }^{2}$ During the very early weeks of the experiment, when "paste food" was inadvertently withheld from the young immediately after weaning, a number of them died or failed to grow satisfactorily. 
The dietary procedure for the major part of the experiment may be summarized as follows:

1. "Calf meal food" to all rats ad libitum.

2. "Paste food" to nursing mothers and to young rats under six weeks of age ad libitum.

3. $3 \mathrm{gm}$. wheat embryo weekly to each rat not supplied with "paste food."

4. $1 \mathrm{gm}$. dried yeast daily to each rat except nursing young.

5. $10 \mathrm{gm}$. lettuce weekly to each rat except nursing young.

There is at present an appreciation, based on accumulating experimental and practical evidence, that an imbalance of such dietary constituents as vitamins, proteins, or minerals may seriously interfere with normal reproduction and development $(9,25,33,12,14,13)$. On the basis of current knowledge, it appears that the foregoing program provides a generous allowance of dietary constituents known to be required for satisfactory reproduction, lactation, and growth of young. The biological value of the protein mixture both of the calf meal and of the paste food is presumably excellent. That the nutritive ratio is satisfactory is assured by the facts that the protein content of the dried calf meal is 22.1 percent, and of the dried paste food 34.9 percent.

Support for this statement may be found in a number of studies that deal with the level of dietary protein. Slonaker $(35,36)$ reported that, under his experimental conditions, reproductive efficiency was greater on the ration which contained approximately 14 percent of protein than on rations with a lesser or greater content. On the other hand, Macomber (16) found that, on a diet containing 20 percent protein, fertility and lactation were optimum as compared with diets with lower protein content. Kozlowska, McCay and Maynard (11) fed diets that contained 10 percent and 40 percent of protein and showed that the lower level was inferior for prolonged lactation. Russell (31) observed good reproductive performance with a ration containing 22 percent protein. In all of these studies, the rat was the species employed. The importance of the rôle of the protein factor, considered both qualitatively and quantitatively, is stressed in a review of recent work on dietary requirements in pregnancy and lactation in various species (8). The earlier literature concerned with the relation of diet to milk secretion was summarized by Meigs (21).

The presence of dried milk, whole grains, and mineral salts in the calf meal fed to our animals makes it certain that the inorganic portion of the ration was satisfactory. Experience with this diet has given every indication of its ability to promote superior skeletal development. ${ }^{1}$. The vitamins required by the rat were amply provided by the dried yeast, whole grains, milk powder, cod liver oil, wheat germ, and lettuce.

The general procedure was the same for all groups of animals. The rats were first bred at 110 to 120 days of age, with three females and one male in each mating cage. At this age, according to Sherman and coworkers $(34,32)$, the store of calcium is large. At the end of three weeks, the females were placed in individual cages and "paste food" was supplied in addition to the "calf meal food." 2 All litters were reduced at birth to

${ }^{1}$ Personal communication from Dr. Maynard with respect to the calf meal moiety and unpublished observations from this laboratory in regard to the complete ration.

${ }^{2}$ In the interest of a more uniform nutritional background for both the mother and the young, the present procedure is to withhold "paste food" until parturition. 
eight rats and the young were weaned at 21 days of age. When the twenty-first day fell on Sunday, the litter was weaned the following day and a correction of $4 \mathrm{gm}$. body weight was made for each rat. Each female was mated four times and no female was bred more than once with the same male. Brother and sister matings were carefully avoided. From the progeny of the last mating of each generation, 18 females and 6 to 8 males of average size and vigor, and as widely distributed over the entire group as possible, were selected as breeders for the following generation.

To initiate the experiment, 18 females were assigned to each of four groups, Ia, Ib, II, and III, the numbers referring to the interval in weeks to be allowed between weanings and subsequent matings. Two groups (Ia and Ib) with an interval of one week between weaning and remating were used. Of these, Group Ib was started somewhat later than the other three groups, and older animals were chosen. The object of this delayed start was to permit the animals of this group to complete the four reproductive cycles at the same time and at the same age as the animals in Group III. It was anticipated that a poor response might be observed in Group Ia, since these animals would be younger than those in Group III for all matings except the first. At the end of the first generation, however, the differences were not sufficiently marked to warrant continued emphasis on this point and, with the start of the second generation, the animals in Group Ib were accorded the same treatment as those in Group Ia. The inclusion of two groups with but one week interval between weanings and matings has furnished an added check on the effect of this shorter interval between reproductive cycles.

Inasmuch as perfect performance with respect to gestation and lactation could not be expected, it was necessary to establish a definite procedure in case of failures. If a female failed to complete a reproductive cycle, either because no litter was cast or through failure to nurse the young, the practice was as follows: If no litter was cast within three weeks after the female was separated from the male, she was immediately remated. If an animal cast a litter, but failed to nurse it more than a day or two, she was remated according to the regular schedule, i.e., one, two, or three weeks from the day the litter was lost.

Groups Ia, Ib, and II were studied through seven generations; Group III through only six generations. The data in regard to fertility, the number of young born and weaned, and the weights of the young at weaning are summarized in Tables 1 to 7 . In connection with the number of females used at each mating, (Column 3 ), attention is called to corrections that have been made in a few cases for failures due to sterile males. During the first and second generations, there were many unproductive matings that appeared to be attributable to the males. As the object of the investigation was to study the relation of the mating interval to reproductive performance, it was important that there be a minimum of irregularity in the mating schedule. Therefore, the practice of "test mating" was started. Each male designated for use was mated at the age of 75 days with a stock female of proved fertility and only males of demonstrated potency were used. This procedure served to stabilize the experiment to a large extent, but did not, of course, prevent occasional failures. There are cases in the records of males that proved potent at the time of 
test mating, but were unsatisfactory as sires throughout much of the actual experiment. In other words, the same sort of uncontrollable variable was present here that occurs in any breeding procedure. Inasmuch as the practice of test mating was not instituted systematically until the start of the fourth generation, and even then did not entirely
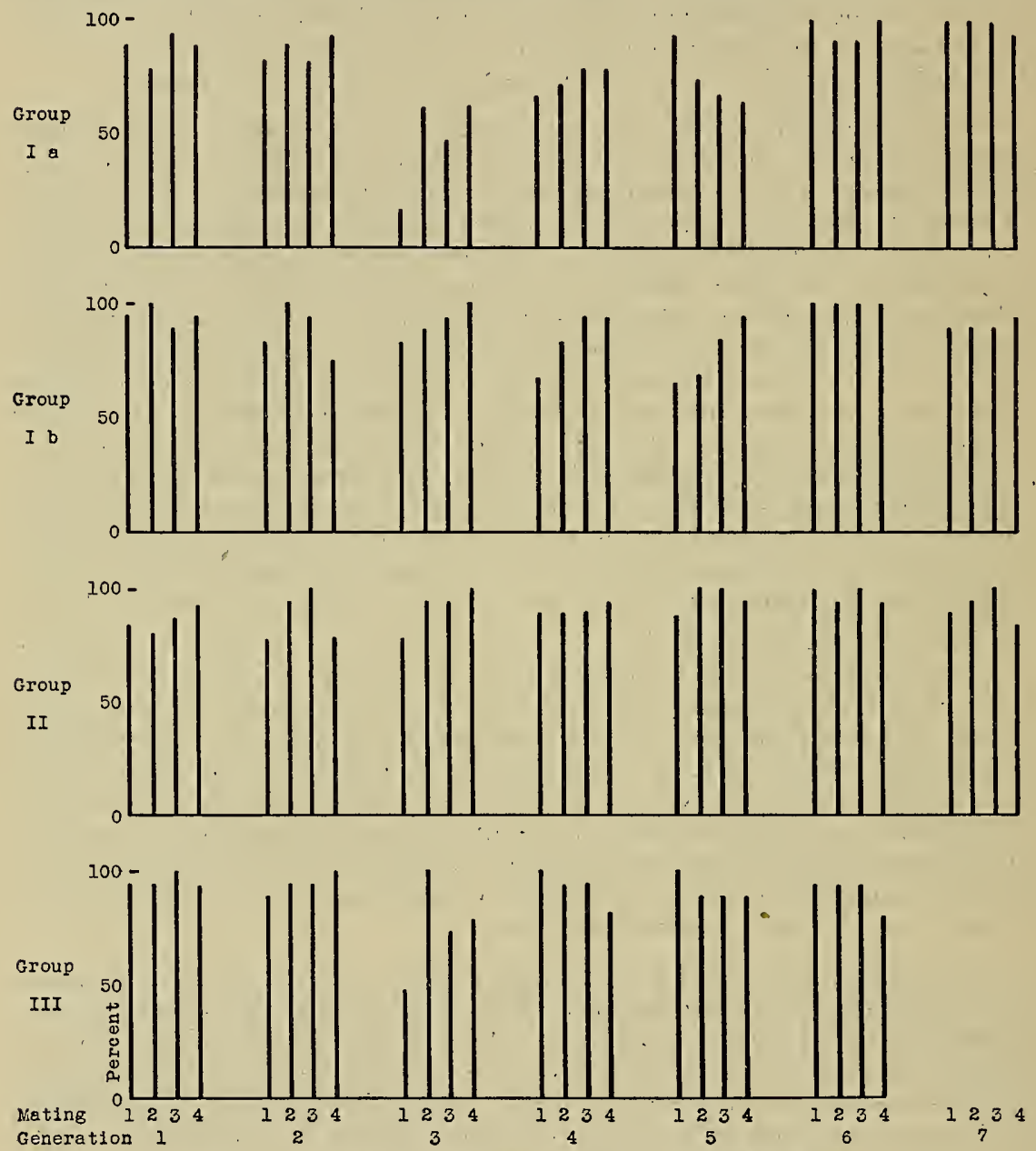

Figure 1. Average percentage of fertility for each mating.

eliminate failures, we have made corrections for the apparent sterile males as indicated in the tables. In making such corrections, a failure of the male was not counted against that particular animal if the female in question was unproductive with three or more males.

\section{Discussion of Results}

From the assembled data, there is no evidence of a close relation between a mating interval of one, two, or three weeks and any phase of the reproductive performance of the animals used in this experiment 
under the dietary conditions imposed. There are variations from time to time, but in general, in so far as fertility, number of young produced and weaned, and weights of young at weaning may be considered adequate criteria, results are essentially the same for the different groups.

In Tables 1 to 7 the term "percentage of fertility" represents the relationship of the fertile to the total matings. The data are also shown graphically in Figure $\mathbf{1}$ and indicate in general the same degree of success in all matings, with the exception of Group Ia and Group III in the third generation: In these instances the first matings were definitely less successful than subsequent ones.

If one calculates an average of the percentage fertility for the individual groups throughout the entire experiment, the following values are obtained: Group Ia, 80.4 percent; Group Ib, 89.5 percent; Group II, 91.8 percent; Group III, 89.6 percent. It appears from this measure of reproductive performance that, except in the case of Group Ia, there is little demonstrable effect of the variations in length of resting period herein employed.

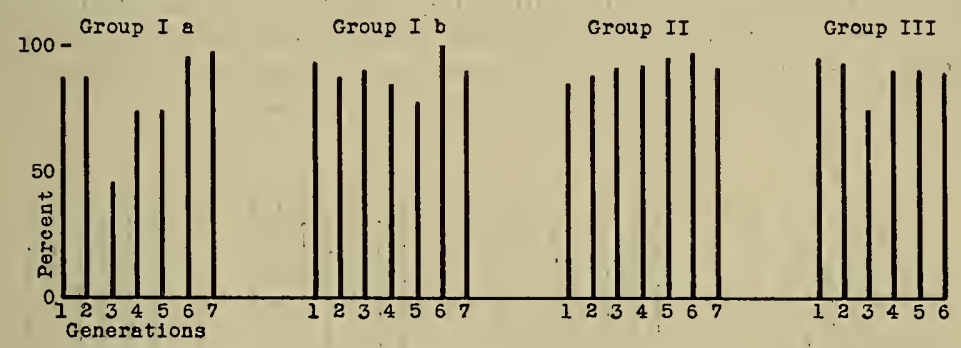

Figure 2. Average percentage of fertility.

An evaluation in the present instance of the variability of the percentage of fertility from generation to generation and from group to group emphasizes anew the necessity for employing large numbers of animals in attempting to evolve generalizations in biological investigations. During the period of the third, and extending over to the fourth and fifth generations, undetermined influences brought about a decrease in the

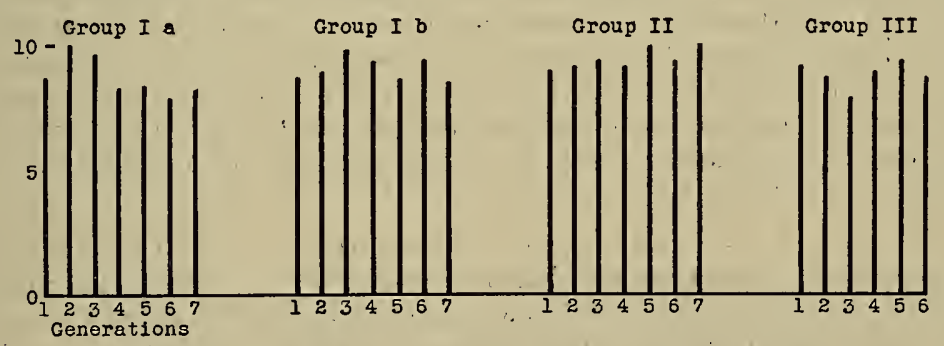

Figure 3. Average number of young born per litter.

percentage of fertility of a large number of rats bred at those times. As may be seen from Figure 2, this occurred in one or another generation in all of the groups except Group II. In the third generation, the decline 
was marked in Group Ia and slight in Group III. In Group Ib there was a decrease in the fourth and fifth, and in both Groups Ia and Ib a marked improvement in the sixth and seventh generations. Attention is called to the uniformly high percentage of fertility in Group II; the mean value for the seven generations of this group is 91.8 percent with an average deviation of only 2.8 percent.

Figure 3 illustrates the average number of young born per litter in successive generations throughout the experiment. The values show little difference between groups or between generations. The general average of the number of young born is high in all groups, the values ranging from 8 to 10 per litter for the entire period of observation, with the possible exception of Group Ia, beginning with the third generation. It may be noted again in this connection that the data for Group II show the high average values of 9 to 10 young per litter with strikingly little variation.

In Tables 1 to 7 (Column 12) are given data for the percentage of young weaned. Inasmuch as all litters immediately after birth were reduced to eight if they exceeded that number, this value represents the relationship between the number of young weaned and the number in the reduced litter. Here again there was a definite tendency toward inferior performance at about the fourth generation. It is obvious (Figure 4) that

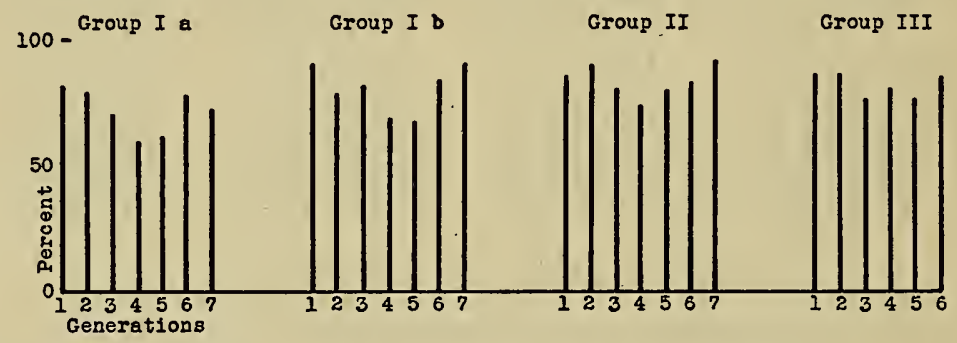

Figure 4. Average percentage of young weaned.

Group Ia presents the poorest record in all generations. On the other hand Groups II and III maintained a relatively superior performance. Group Ia showed a minimum in the fourth, Group Ib in the fifth, Group II in the fourth, and Group III in the third and fifth generations. Inasmuch as the duration of the generation in various groups differed considerably, it appears that the decrease in percentage weaned cannot be attributed to seasonal environment. Rather it would seem to be associated with constitutional factors which in turn are conditioned by the reproductive stress. Such factors include congenital vigor or debility as well as the efficiency of lactation.

The data on weaning weights indicate that, under the conditions of this experiment, lactation was highly satisfactory. Except for Group Ia in the fifth generation, and the females of Group II in the fourth generation, the average body weights of the young at weaning were $40 \mathrm{gm}$. to $45 \mathrm{gm}$. and were strikingly uniform. It is thus obvious that the variation in mating interval played no significant rôle in influencing the weights of the young at weaning. These weights compare favorably with those reported by Smith and Bing (37) who used the same strain but a different diet, and 
by Russell (31) who used both a different strain and a different diet. On the other hand, in the parent colony from which this stock was taken, the weaning weights averaged 47 to $48 \mathrm{gm}$. in 1934 (23). Current figures from this colony indicate a trend toward still higher weaning weights.

For some reason that is not entirely clear to us, the performance of the animals in Group Ia was definitely inferior to that of the animals in Group Ib with the same treatment throughout. We have analyzed the data for possible reasons for this difference without finding an explanation that is adequate. The suggestion is made that the poorer behavior is due in some measure to the chance assembling of inferior material at the start. A study of the genealogy of each group shows that in Group Ia the number of females that produced litters in the fourth matings and therefore provided material for the succeeding generations declined mucb more rapidly than in Group Ib. In Table 8 are recorded the total number of females available in each generation in terms of the original 18. For example, of the 18 in the first generation, only 5 of those in Group Ia are represented by the animals available in the sixth generation, while in Group Ib those in the sixth generation may be traced back to 10 of the original 18 females. A comparison of the two groups with respect to the average percentage weaned in all matings (Figure 4) and the average percentage weaned in the fourth mating alone (Figure 5) emphasizes the

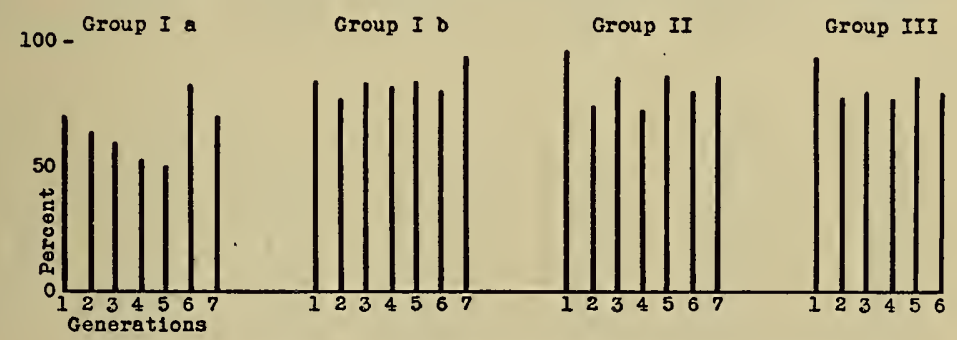

Figure 5. Average percentage of young weaned, fourth mating.

inferiority of Group Ia throughout, but particularly in the fourth matings. The foregoing possible explanation of the difference between the behavior of $\mathrm{Ia}$ and $\mathrm{Ib}$ is further supported by the data on which Figure 6 is based. Here it is plain that, whereas the success of the individual reproductive cycles, as indicated by the average percentage weaned, is low in the fourth mating of Group Ia in comparison with the other matings, the reverse is true in the case of Group Ib. This observation is of particular significance since the progeny of the fourth matings provided animals for the following generation.

From Table VIII, it is evident that there was a similar decrease in the number of females in Group II. In view of the superior performance of Group II as judged by all the measures employed, it would appear that the longer rest interval compensated for the influence of the factors which tended to cause the poor performance in Group Ia. The same line of reasoning may also be offered for comparison of Group III with Group Ia (Fig. 6). 
Evidences are presented of the more or less regular biological variations which have been manifested in the course of this investigation. As has been pointed out in the foregoing discussion, several measures of performance indicated a marked decrease in efficiency extending from the third through the fifth generation. It is striking that these variations appear to be more or less independent of the interval between matings or of the
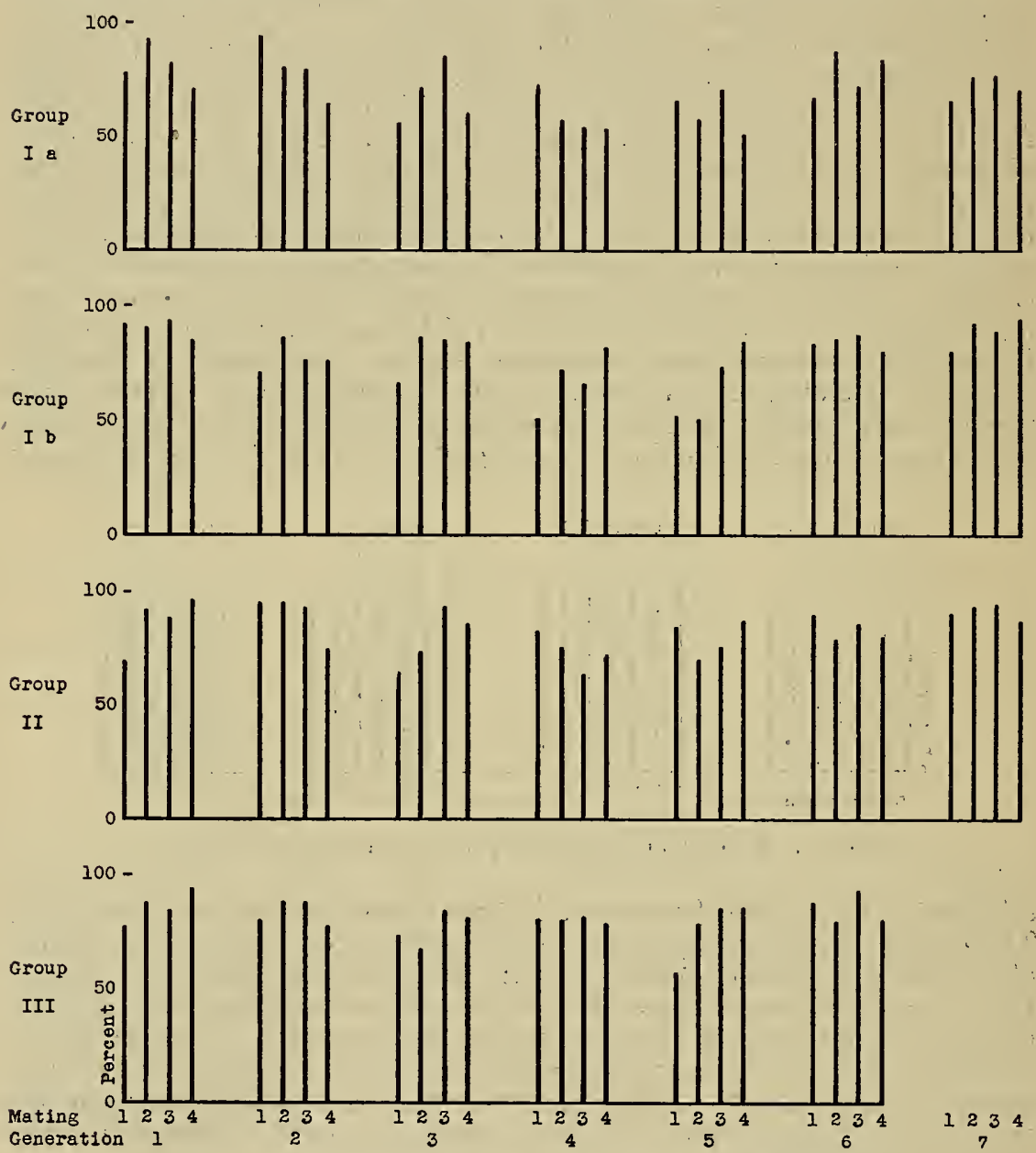

Figure 6. Average percentage of young weaned per mating.

season of the year. Of equal interest is the prompt recovery to high levels of performance in the interval covered by the sixth and seventh generations. It is possible that, had the experiment been extended, similar cyclic variations might have recurred. Even in an experiment as carefully controlled as the present one, these fluctuations in reproductive performance were not entirely eliminated. 


\section{SUMMARY}

The reproductive performance of a selected group of albino rats has been studied over a period of six years under favorable conditions of nutrition. Particular attention was devoted to the influence of mating interval as measured by certain specific criteria, namely percentage of fertility, number of young born, percentage weaned, and weights of young at weaning. Although the results obtained were essentially the same in all groups, it appears that an interval of two weeks between weaning a litter and remating is slightly more favorable for reproductive success. With this two-week interval, the following results were obtained: percentage of fertility 91.8; average number born per litter 9.4; average percentage weaned per reduced litter 83.2, and weaning weights of the young, males $43 \mathrm{gm}$., females $42 \mathrm{gm}$.

In view of certain difficulties that seem to be attributable to restricted selection in breeding stock, the present study may be said to represent the minimum to be expected under the experimental procedure employed. The optimum should be obtained when a wider choice is made in selecting breeders. 


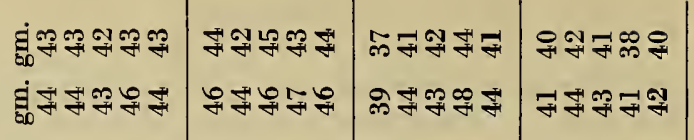

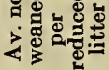

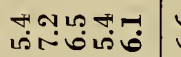
소용

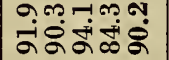

ด다.

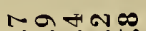

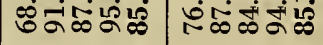

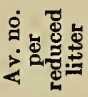
宫茟 裙票 ํㅜㅇㅠ. 20 $-10.000$

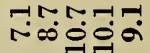

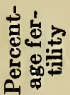
a)

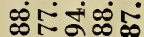

7. $0.0 \pi+4$

molom

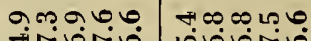

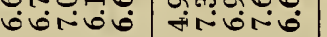

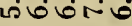

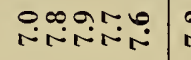

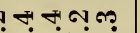

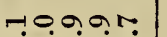

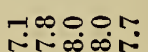

용 :

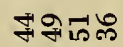

Nํㅇㄴㅡ

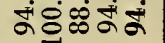

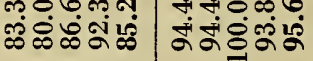

悉

ํ.

쿠듀요

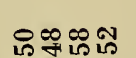

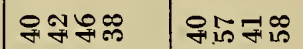

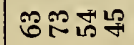

舟乐术路。

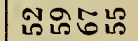

(1)

พับนก

๓ 79

(1)

(1)

ะ๐ำ

พิพิ่พัพิ

그요국

구규 


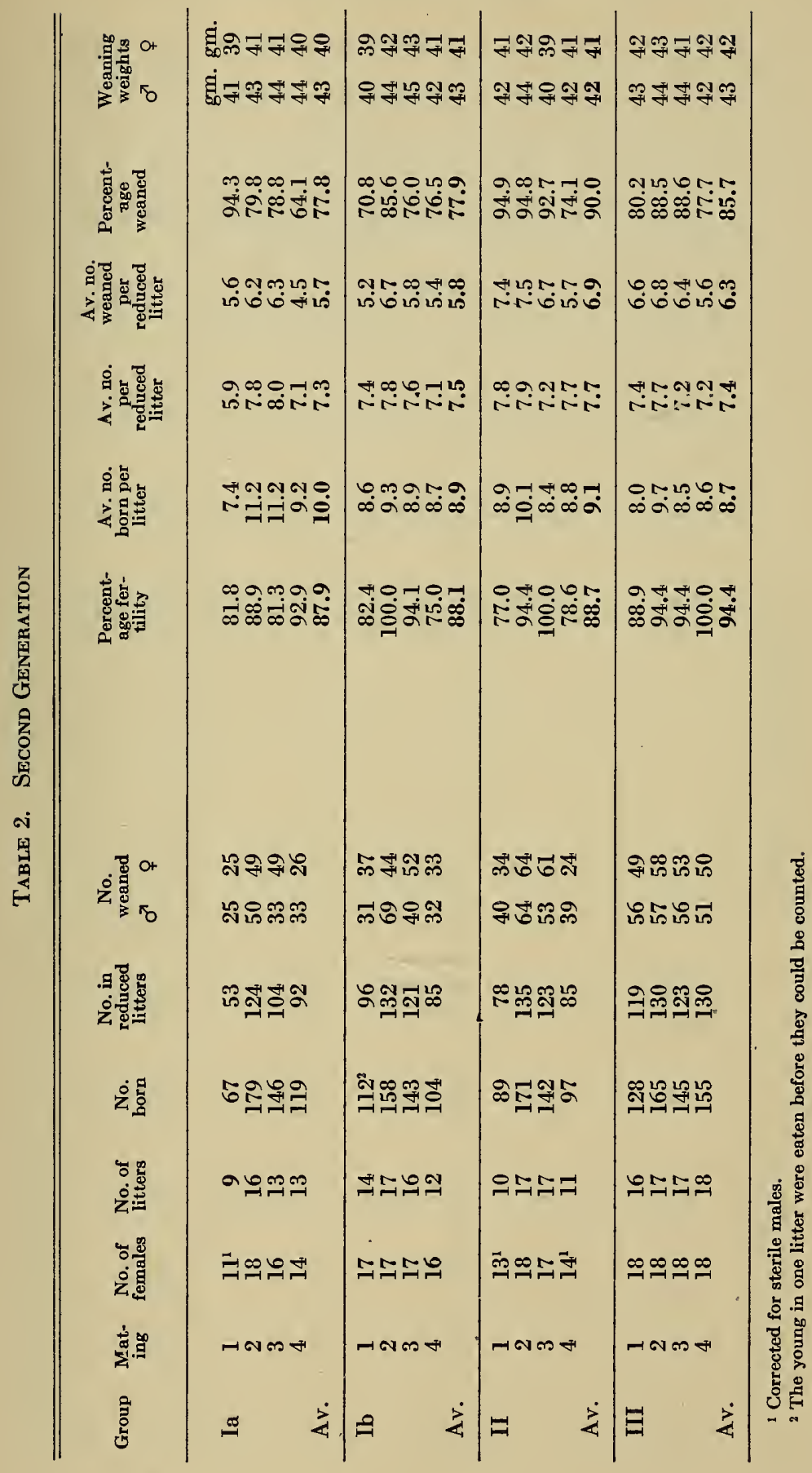




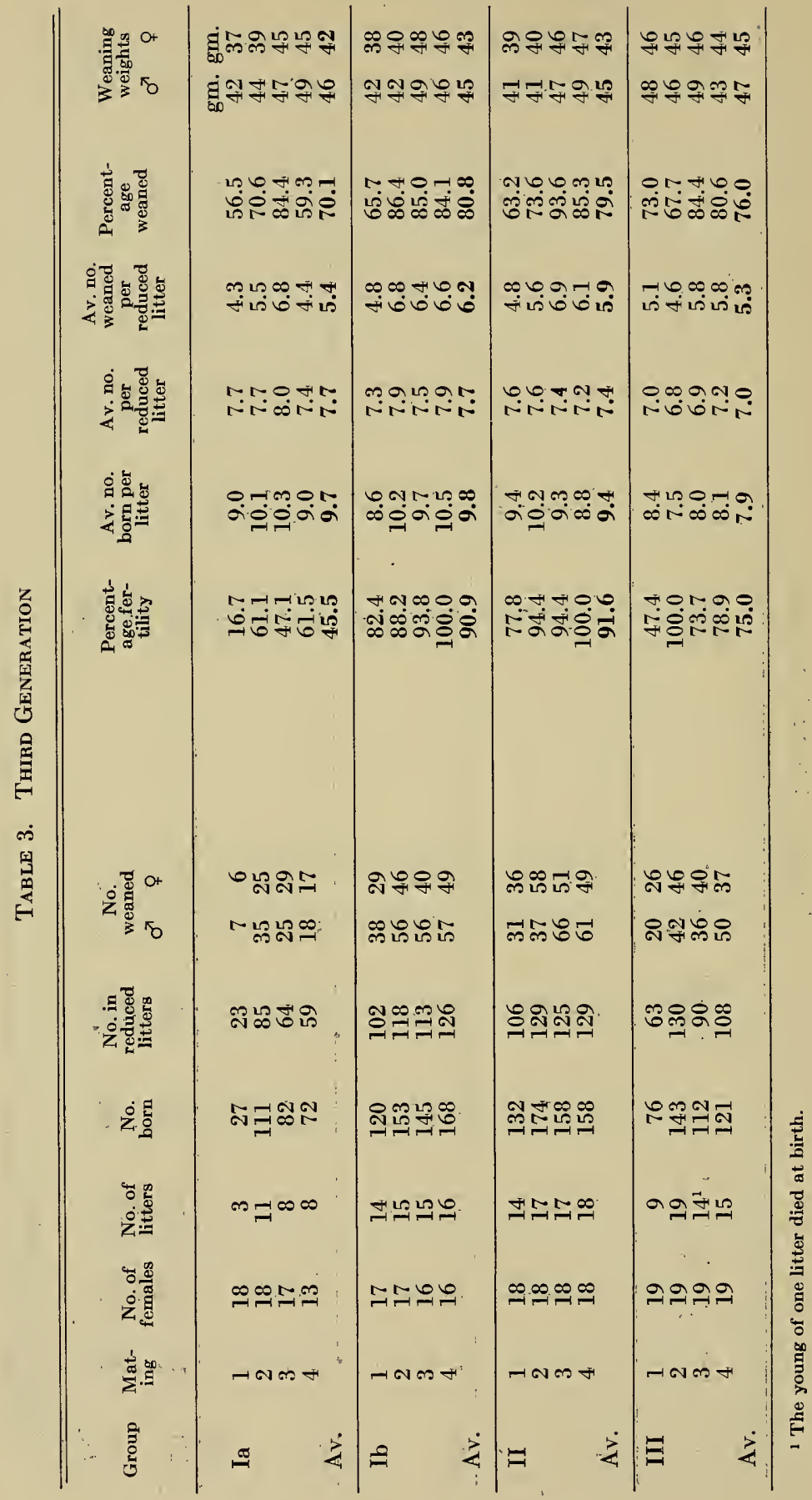




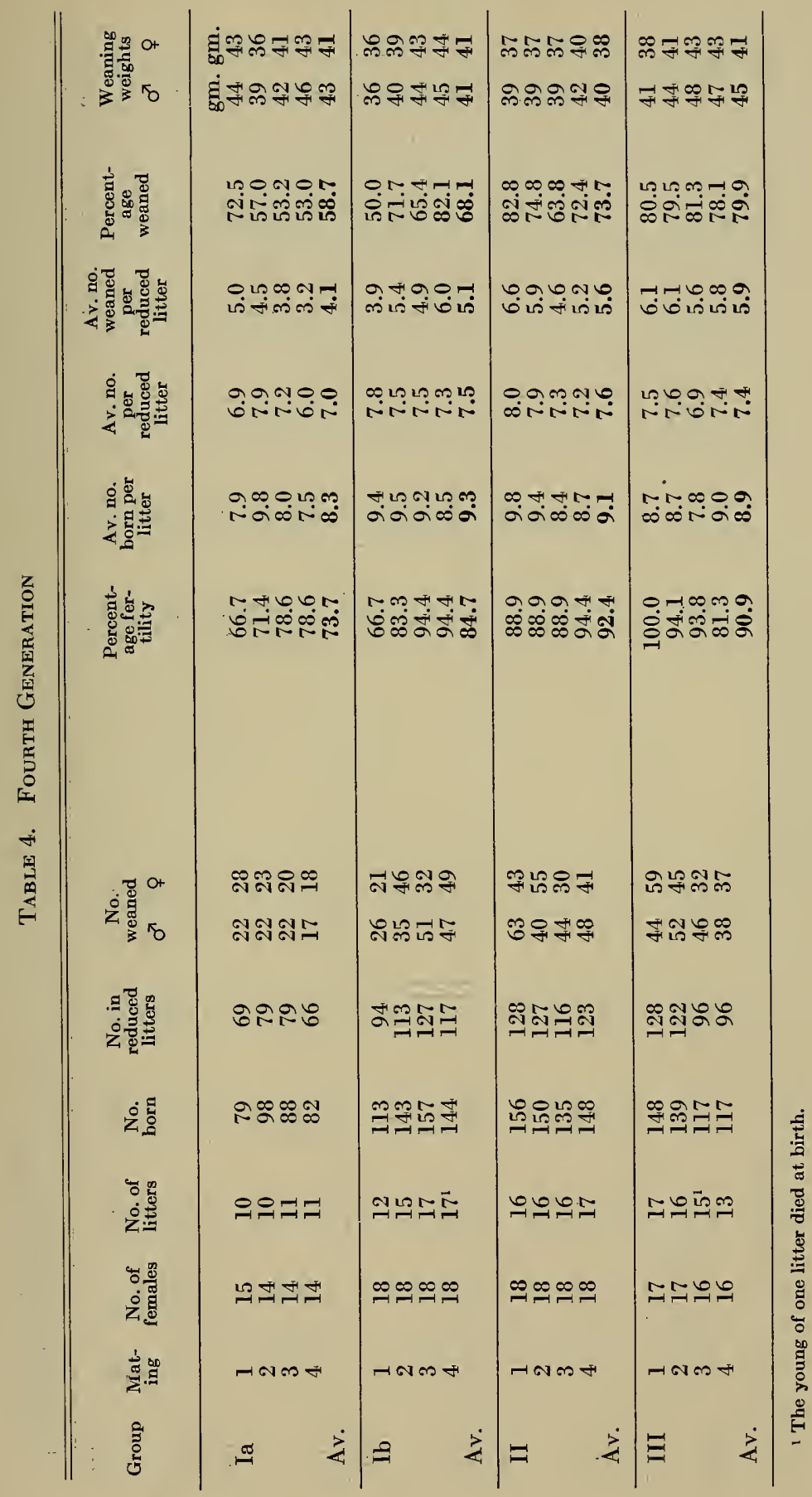




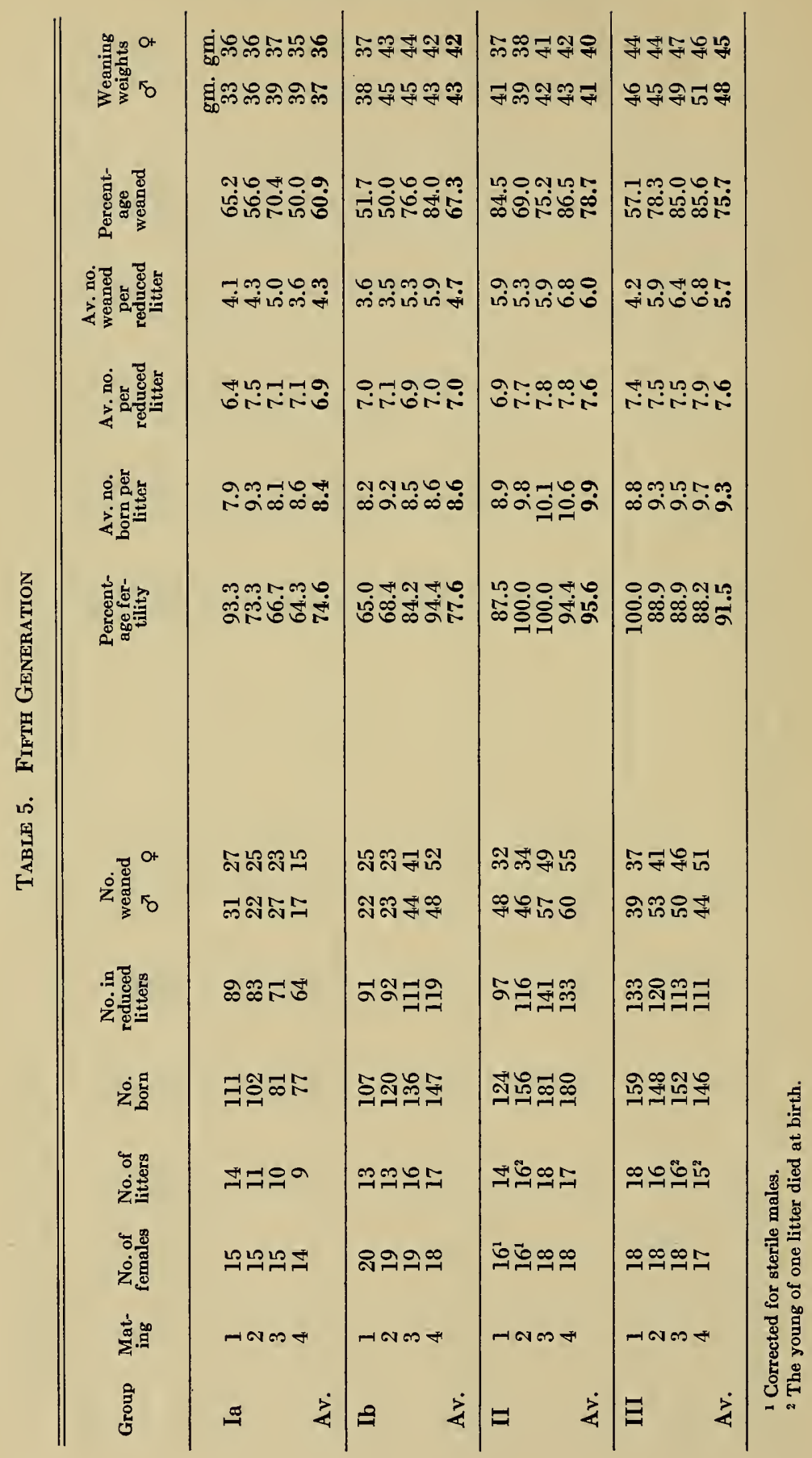




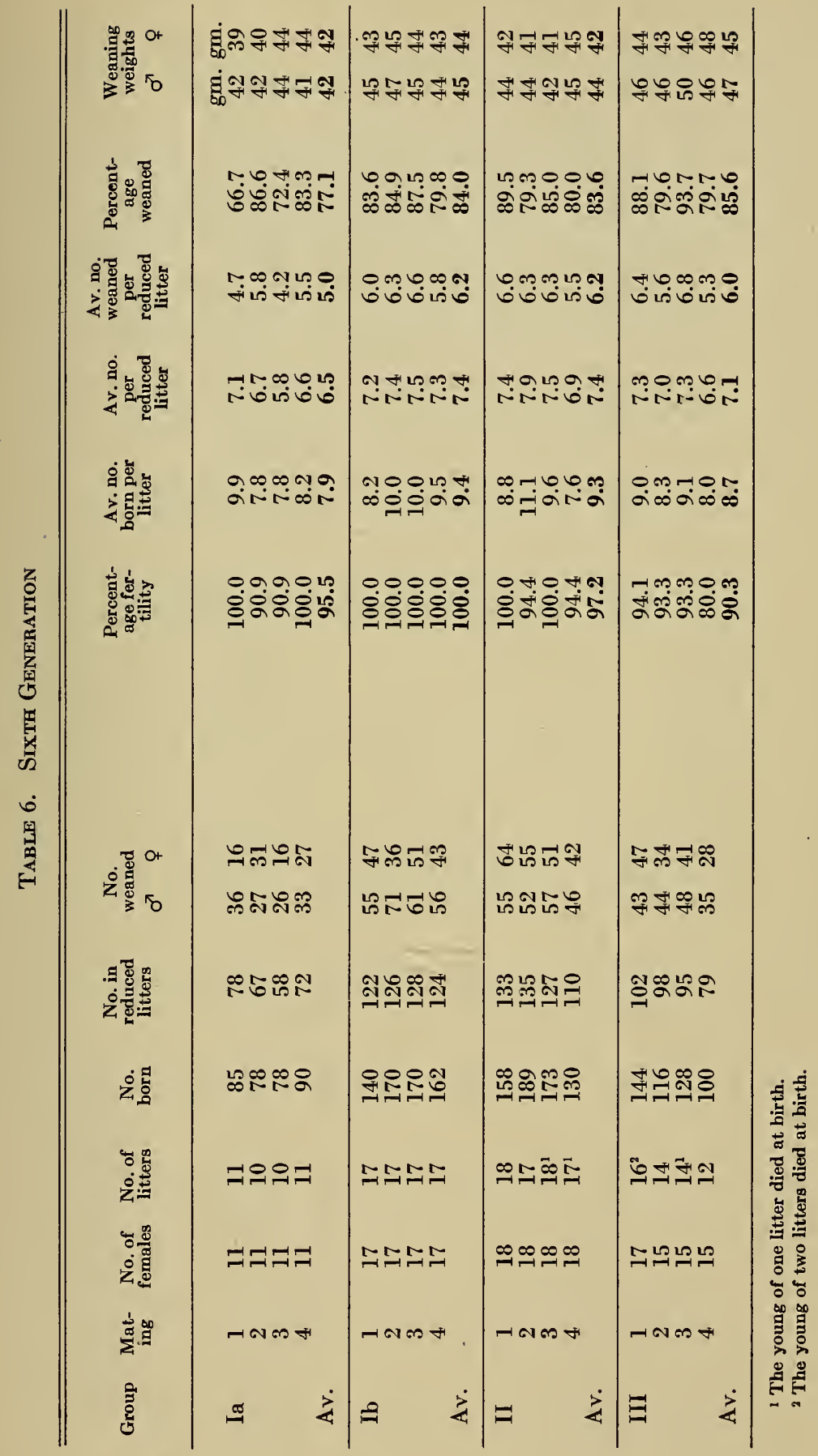




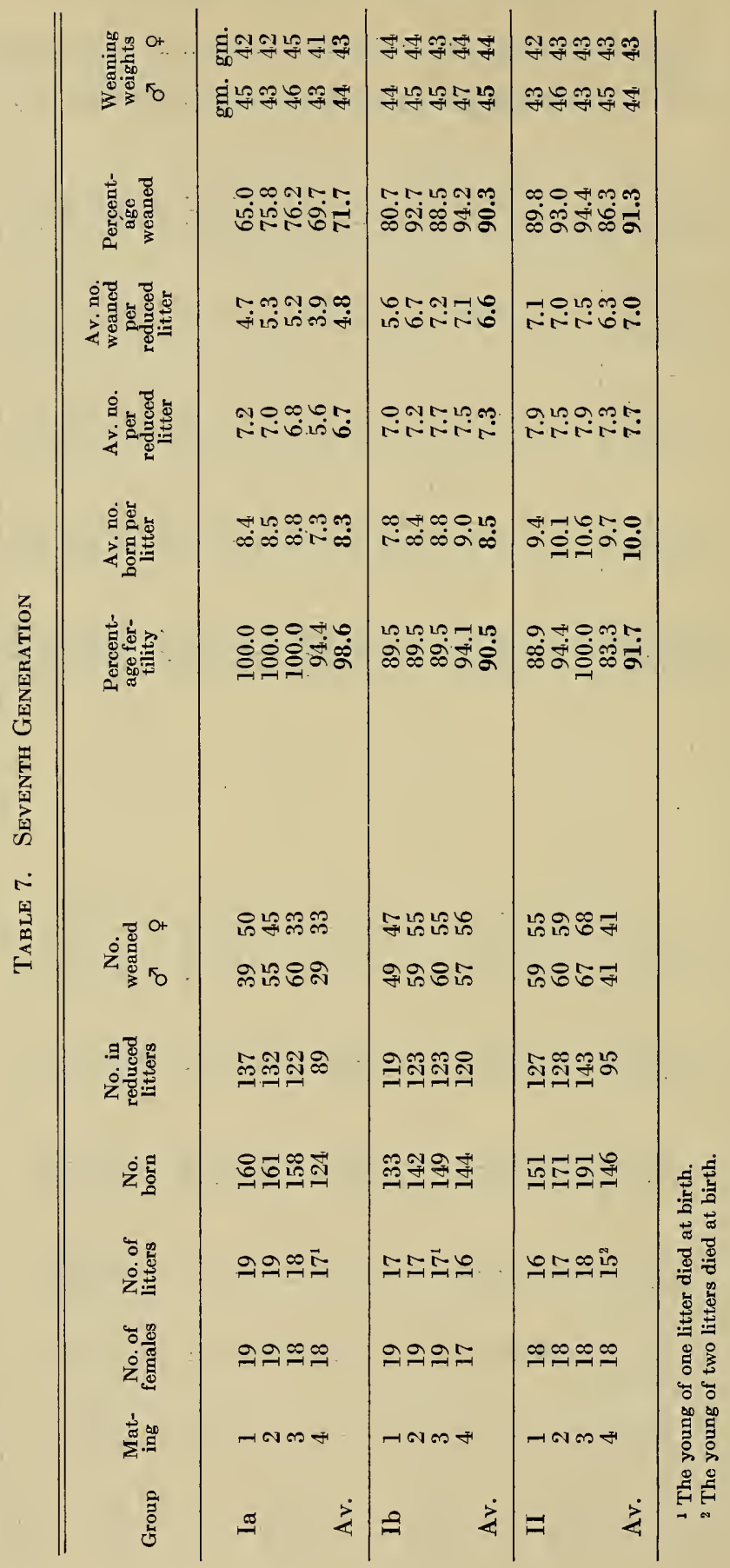




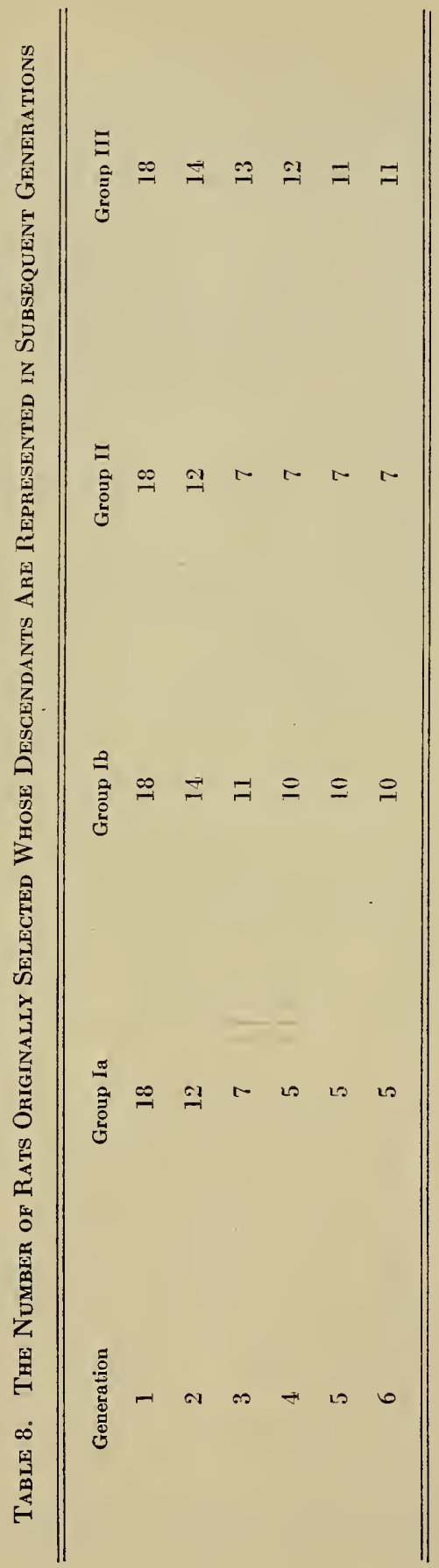




\section{BIBLIOGRAPHY}

1. Anderson, W. E., and Smith, A. H. Further observations of rapid growth of the albino rat. Amer. Jour. Physiol., 100: 511. 1932.

2. Batchelder, E. L. Nutritional significance of vitamin A throughout the life cycle. Amer. Jour. Physiol., 109: 430. 1934.

3. Cummings, M. J., and Mattill, H. A. The auto-oxidation of fats with reference to their destructive effect on vitamin E. Jour. Nutrition, 3: 421. 1931.

4. Donaldson, H. H. A comparison of the white rat with man in respect to the growth of the entire body. Boas Anniversary Volume, New York, pp. 5-26. 1906.

5. Donaldson, H. H. The Rat, 2nd edition. Philadelphia. 1924.

6. Evans, H. M., and Bishop, K.S. On the relations between fertility and nutrition. II. The ovulation rhythm in the rat on inadequate nutritional regimes. Jour. Metabolic Research, 1: 335. 1922.

7. Evans, H. M., and Burr, G. A. Vitamin E. The ineffectiveness of curative dosage when mixed with diets containing high proportions of certain fats. Jour. Amer. Med. Assn., 88: 1462.1927.

8. Garry, R. C., and Stiven, D. A review of recent work on dietary requirements in pregnancy and lactation, with an attempt to assess human requirements. Nutrition Abstracts and Reviews, 5: 755. 1936.

9. Hart, E. B., Steenbock, H., Humphrey, G. C., and Hulce, R. S. New observations and a reinterpretation of old observations on the nutritive value of the wheat plant. Jour. Biol. Chem., 62: 315. 1924.

10. King, H. D. Growth and variability in the body weight of the albino rat. Anat. Rec., 9: 751. 1915.

11. Kozlowska, M., McCay, C. M., and Maynard, L. A. A technic for studying lactation in small animals and its use in evaluating protein levels in the diet. Jour. Nutrition, 5: 61. 1932.

12. Leitch, I. Nutrition in relation to reproduction, with special reference to sterility. Nutrition Abstracts and Reviews, 2: 451. 1933.

13. Macomber, D. Effect of a diet low in calcium on fertility, pregnancy and lactation in the rat. Jour. Amer. Med. Assn., 88: 6. 1927.

14. Macomber, D. Studies of reproduction in the rat. I. The effect of changes in the protein upon fertility, pregnancy and lactation. New Eng. Jour: Med., 209: 1105. 1933.

15. Macomber, D. Studies of reproduction in the rat. III. Vitamin E-neutralized when mixed with lard. New Eng. Jour. Med., 209: 1235. 1933.

16. Macomber, D. The effect of changes in the amount of protein upon pregnancy and lactation. Amer. Jour. Obstetrics and Gynecology, 27: 483. 1934.

17. Mason, K. E., and Ellison, E. T. Vaginal cornification as a criterion of vitamin A deficiency in the rat. Anat. Rec., 58 suppl.: 80. 1934.

18. Mason, K. E., and Ellison, E. T. Changes in the vaginal epithelium of the rat after vitamin A-deficiency. Jour. Nutrition, 9: 735. 1935.

19. Mason, K. E., and Ellison, E. T. The demonstration of oestrus in the vitamin Adeficient rat by supravital study of the vaginal smears. Jour. Nutrition, 10: 1. 1935.

20. Maynard, L. A. A diet for stock rats. Science, 71: 192. 1930.

21. Meigs, E. B. Milk secretion as related to diet. Physiol. Reviews, 2: 204. 1922.

22. Mendel, L. B., and Cannon, H. C. The relation of the rate of growth to diet. II. Jour. Biol. Chem., 75: 779. 1927.

23. Mendel, L. B., and Hubbell, R. B. The relation of the rate of growth to diet. III. A comparison of stock rations used in the breeding colony at the Connecticut Agricultural Experiment Station. Jour. Nutrition, 10: 557. 1935. 
24. Mendel, L. B., Hubbell, R. B., and Wakeman, A. J. The influence of some commonly used salt mixtures upon growth and bone development of the albino rat. Jour. Nutrition, 14: 261. 1937.

25. Nelson, P. M. Maternal diet and lactation. Jour. Home Econ., 18: 383. 1926.

26. Osborne, T. B., and Mendel, L. B. Feeding experiments with isolated foodsubstances. Carnegie Inst. Washington, Pub. 156. 1911.

27. Osborne, T. B., and Mendel, L. B. The role of different proteins in nutrition and growth. Science, 34: 722. 1911.

28. Osborne, T. B., and Mendel, L. B. The relation of the rate of growth to diet. I. Jour. Biol. Chem., 69: 661. 1926.

29. Outhouse, J., and Mendel, L. B. The rate of growth. I. Its influence on the skeletal development of the albino rat. Jour. Exper. Zool., 64: 257. 1933.

30. Pickens, M. The chemical composition of the increment of growth at different rates of growth. Dissertation, Yale. 1937.

31. Russell, W. C. The addition of raw beef or meat scrap to a wheat-milk diet. Jour. Nutrition, 5: 347. 1932.

32. Sherman, H. C., and Booher, L. E. The calcium content of the body in relation to that of the food. Jour. Biol. Chem., 93: 93. 1931.

33. Sherman, H. C., and Campbell, H. L. Growth and reproduction upon simplified food supply. IV. Improvement in nutrition resulting from an increased proportion of milk in the diet. Jour. Biol. Chem., 60: 5. 1924.

34. Sherman, H. C., and MacLeod, F. L. Calcium content of the body in relation to age, growth, and food. Jour. Biol. Chem., 64: 429. 1925.

35. Slonaker, J. R. The effect of different percents of protein in the diet. I. Growth. Amer. Jour. Physiol., 96: 547. 1931.

36. Slonaker, J. R. The effect of different percents of protein in the diet. IV. Reproduction. Amer. Jour. Physiol., 97: 322. 1931.

37. Smith, A. H., and Bing, F. C. Improved rate of growth of stock albino rats. Jour. Nutrition, 1: 179.1928.

38. Sure, B. Dietary requirements for fertility and lactation. XXII. Further studies of the role of milk fat in fertility and lactation. Jour. Nutrition, 2: 485 . 1930. 


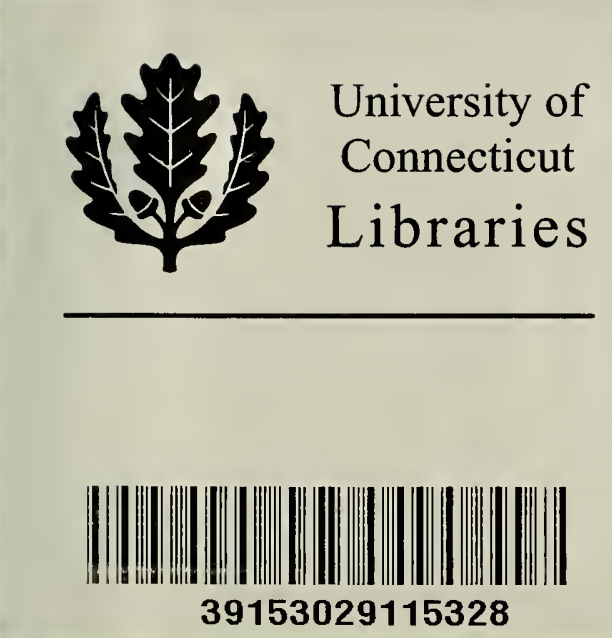
